\title{
ХАРАКТЕРИСТИКА ЛЕТАЛЬНОСТІ ПРИ ЛЕПТОСПІРОЗІ В ЧЕРНІВЕЦЬКІЙ ОБЛАСТІ
}

\author{
${ }^{1}$ ДУ «Інститут епідеміології та інфекційних хвороб ім. Л.В. Громашевського НАМН України», \\ ${ }^{2}$ ДУ «Чернівецький обласний лабораторний центр МОЗ України»
}

Лептоспіроз є одним з найбільших викликів громадському здоров'ю Чернівецької області серед зоонозних інфрекційних хвороб.

Мета роботи - дати характеристику летальності від лептоспірозу на прикладі Чернівецької області та визначити фрактори, що підвищують ії ризик.

Матеріали і методи. Використовували епідеміологічний, серологічний та статистичний методи дослідження, дані Державної установи «Чернівецький обласний лабораторний центр МОЗ України» (20062016 рр.) щодо захворюваності та летальності при лептоспірозі в області, результати епідеміологічного розслідування всіх зареєстрованих випадків лептоспірозу (283 випадки, зокрема 32 летальних), результати усного опитування 157 респондентів для оцінки обізнаності сільського населення щодо лептоспірозу. Етіологію захворювань визначали за наявністю специсрічних антитіл у реакції мікроаглютинації з використанням некомерційного діагностичного набору штамів лептоспір.

Результати досліджень і висновки. На тлі тенденції до зниження захворюваності на лептоспіроз протягом періоду спостереження у Чернівецькій області відзначено стійку тенденцію до зростання летальності. її середній показник складав 11,3 \% при загальнодержавному 9,6 \% та в окремі роки коливався від 3,6 \% (2008 р.) до 57,1 \% (2016 р.). Серед летальних випадків лабораторно підтверджено лише 59,4\%. Серед фракторів ризику тяжкого ступеня недуги та вищої летальності слід зазначити етіологічну роль L. icterohaemorrhagiae, вік пацієнтів 60 років і старше, пізнє звернення за медичною допомогою, пізню постановку діагнозу після звернення. Серед пацієнтів із лабораторно підтвердженим діагнозом антитіла до L. icterohaemorrhagiae було визначено у $61,8 \%$ пацієнтів із тяжким ступенем захворювання та у 63,2 \% померлих. Серед усіх захворілих цей показник становив лише 33,7 \%. Серед померлих пацієнтів особи віком 60 років і старше становили $62,5 \%$. За медичною допомогою на 5-10-у добу звернулося 59,4 \% осіб проти 44,1 \%, в яких захворювання закінчилося одужанням. Пізнє звернення за медичною допомогою обумовлено низькою обізнаністю населення. Серед опитаних сільських жителів лише кожен десятий відзначив обізнаність щодо цієї інфрекції. Збіг первинного і кінцевого діагнозів зареєстровано лише в 3,4-23,3 \% випадків. Серед захворілих на лептоспіроз і серед померлих переважали сільські жителі (відповідно 74,6 та 65,6 \%).

Ключові слова: лептоспіроз, летальність при лептоспірозі, L. icterohaemorrhagiae.

У сучасних умовах проблема лептоспірозу набуває все більшого значення. Середній щорічний показник зареєстрованих випадків лептоспірозу у світі становить 1,03 млн (від 434 тис. до 1,75 млн), серед яких 58900 закінчуються летально [1]. Зокрема, за даними річного епідеміологічного звіту [2], повідомлення про випадки лептоспірозу було отримано з 27 європейських країн. Загальна кількість підтверджених випадків коливалася від 489 у 2012 р. до 602 у 2010 р., що становило відповідно 0,11 та 0,13 на 100 тис. населення. Найвищу захворюваність було зареєстровано на Мальті в 2012 р. (0,72 на 100 тис. населення), а також у Словаччині та сусідній з Україною Румунії (відповідно 0,44 та 0,46 на 100 тис. населення) [2]. Спорадичні випадки мали місце практично у всіх країнах за винятком Ісландії, Норвегії, Люксембургу [2, 3]. Ця інсрекція розповсюджена в країнах 3 тропічним кліматом [3], наприклад, щорічно біля 680 випадків захворювань та 40 летальних випадків реєструється на Філіппінах [4]. Лептоспіроз є досить розповсюдженим захворюванням в Південній Азії, Латинській Америці, Океанії та Карибському басейні [5-8].

Летальні випадки при лептоспірозі реєструються також в усіх областях України [9], і Чернівецька область не $є$ винятком. 3 початку 1990-х років лептоспіроз $є$ найпоширенішою природно-осередковою хворобою в Україні з високим відсотком тяжких клінічних фрорм і летальності [10]. Крім цього, складна економічна ситуація в 
Україні в умовах перегляду системи епідеміологічного нагляду та ветеринарного контролю, зниження обсягів дератизаційних заходів дозволяє прогнозувати збереження актуальності проблеми й надалі.

Метою дослідження було охарактеризувати летальність при лептоспірозі на прикладі Чернівецької обл. та визначити фрактори, що підвищують її ризик.

\section{Матеріали і методи}

Для досягнення мети використовували епідеміологічний, серологічний та статистичний методи дослідження. Було проаналізовано офріційні статистичні дані Державної установи «Чернівецький обласний лабораторний центр МО3 України» за період 2006-2016 рр. щодо захворюваності та летальності при лептоспірозі в області, результати епідеміологічного розслідування 283 випадків лептоспірозу, у тому числі з летальним вислідом (32 випадки), та результати усного опитування 157 респондентів для оцінки рівня обізнаності сільського населення щодо цієї інфрекції. Для визначення етіології захворювань за наявністю специфрічних антитіл застосовували реакцію мікроаглютинації 3 використанням некомерційного діагностичного набору штамів лептоспір, яка для серологічної діагностики лептоспірозу вважається «золотим стандартом» [11], оскільки характеризується високою специфічністю.

\section{Результати досліджень та їх обговорення}

Рівень захворюваності на лептоспіроз у Чернівецькій області впродовж 2006-2016 рр. мав тенденцію до зниження (мал. 1), у той час як для летальності при цій інфекції спостерігалася зворотна тенденція (мал. 2). Упродовж періоду спостереження, за даними офіційної статистики, від лептоспірозу померло 32 (11,3 \%) особи

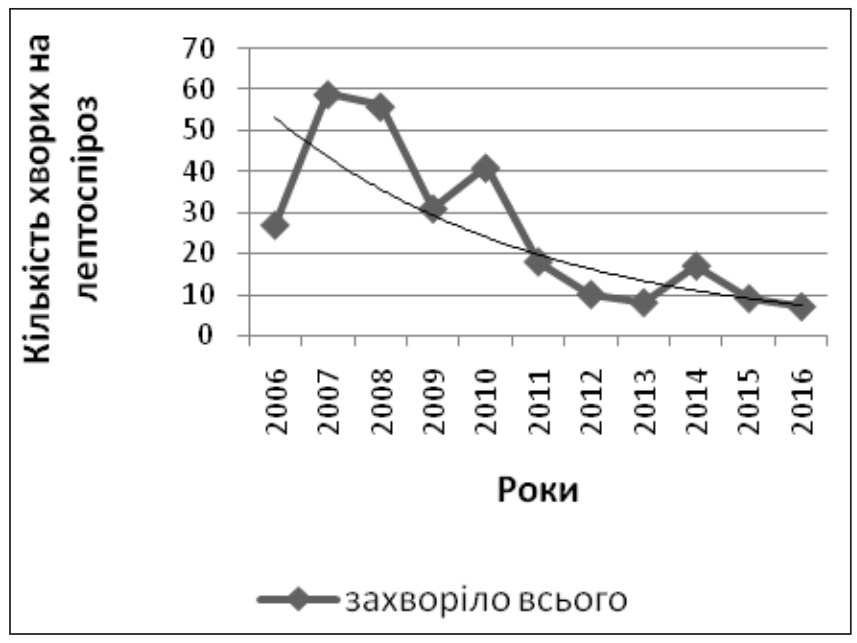

Мал. 1. Динаміка захворюваності на лептоспіроз в Чернівецькій обл. (2006-2016 рр.). при загальній кількості захворілих 283. Летальні випадки реєструвалися щороку, крім 2013 р. Показник летальності за цей період складав 11,3 \% при загальнодержавному 9,6 \% і за роками дослідження коливався від 3,6 \% (2008 р.) до 57,1 \% (2016 р.) (мал. 2).

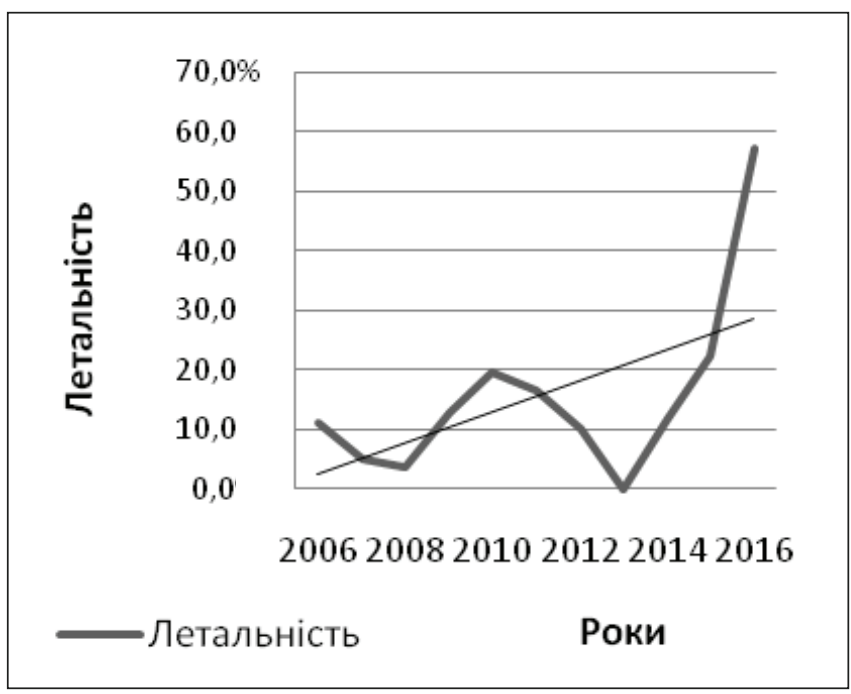

Мал. 2. Динаміка летальності при лептоспірозі в Чернівецькій області (2006-2016 рр.).

Загалом впродовж досліджуваного періоду серед померлих від лептоспірозу частка працездатних осіб вікових груп 20-29 та 30-59 років становила відповідно 6,3 \% (2 особи) та 37,5 \% (12 осіб), а пацієнтів 60 років і старше - 56,2 \% (18 осіб) (мал. 3). Протягом періоду 2006-2010 рр. серед померлих переважали особи працездатного віку за винятком 2009 р. (25 \%) та 2008 р. (50\%). Починаючи з 2011 р., спостерігалося збільшення частки осіб віком 60 років і старше (з 66,7 до 100,0 \%).

Серед померлих переважали чоловіки - 21 пацієнт (65,6 \%). Їх частка в різні роки складала від 30 \% (у 2007 р.) до 100 \% (у 2006 та 2014 рр.). Переважання чоловіків серед померлих обумовлено тим, що за період спостереження частка пацієнтів чоловічої статі серед всіх захворілих на лептоспіроз склала 80,6 \% (228 пацієнтів). Також серед померлих переважали сільські жителі (20 пацієнтів - 62,5 \%). Така закономірність спостерігалась протягом усіх років спостереження за винятком 2007 та 2012 рр., коли частка міських жителів склала 66,7 та 100,0 \% (1 випадок) відповідно. У 2014 та 2015 рр. реєструвалося по 1 летальному випадку серед міських і сільських жителів і цей показник становив 50 \%. Той фракт, що серед померлих пацієнтів переважали сільські жителі, можна пояснити переважанням сільського контингенту серед усіх хворих (74,6 \% за весь період дослідження), що, у свою чергу, пов'язано з їх 


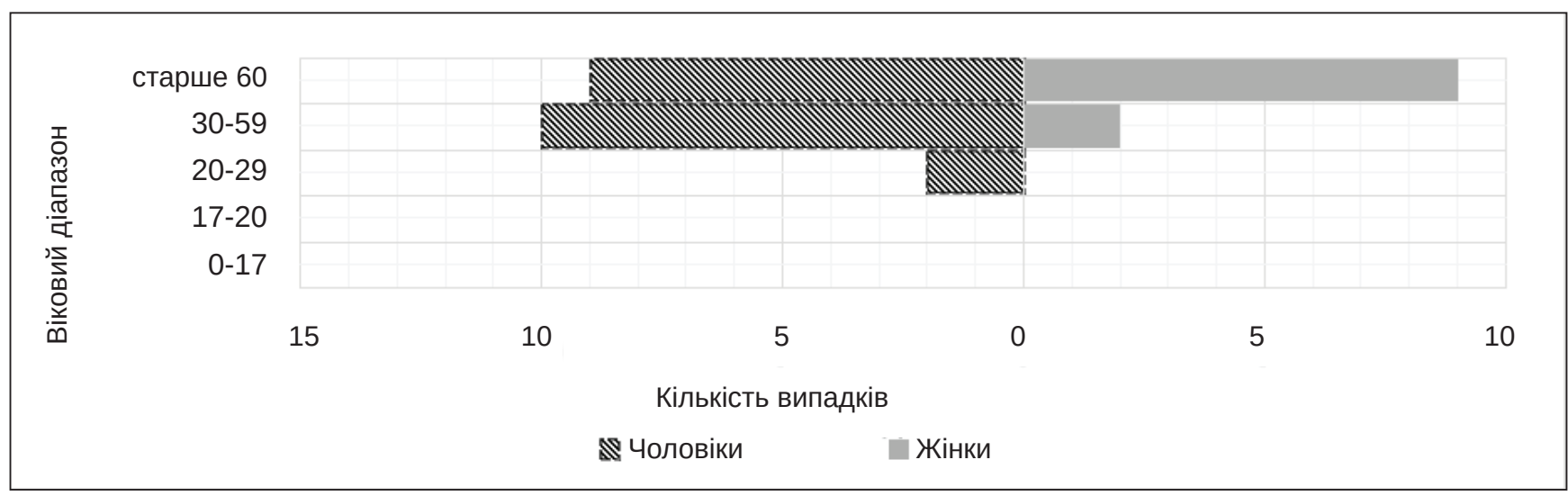

Мал. 3. Розподіл померлих від лептоспірозу в Чернівецькій обл. за віком та статтю (2006-2016рр.).

зайнятістю сільськогосподарськими роботами та доглядом за тваринами, що є загальновизнаними чинниками ризику зараження лептоспірозом. Захворюваність городян за результатами проведених розслідувань пов'язуємо передусім з роботою на дачних ділянках, розташованих в природних осередках лептоспірозу, а також з активним відпочинком - відвідуванням водойм, лісових масивів, рибальством. Випадків професійного зараження в області не зареєстровано.

Проаналізовано залежність ступеня тяжкості та летальності від певних серогруп збудників. Загалом серед захворілих на лептоспіроз тяжкий ступінь встановлено у 118 осіб (41,7 \% від усіх захворілих). Серед цієї категорії пацієнтів діагноз було підтверджено лабораторно у 102 пацієнтів, а антитіла до L. icterohaemorrhagiae визначено у 61,8 \% (63 особи). Встановили зростання цього показника з 62,5 \% у 2011 р. до 100,0 \% та 75,0 \% у 2015 і 2016 р. відповідно. У той же час серед усіх хворих з ла- бораторно підтвердженим діагнозом антитіла до лептоспір L. icterohaemorrhagiae було виявлено лише в 33,7 \% випадків (84 особи). Також визначали антитіла до серогруп hebdomadis, pomona, grippotyphosa (25,7, 20,9 та 13,7\% відповідно). У невеликому відсотку виявлено антитіла до лептоспір canicola (2,8\%) та tarassovi (0,8 \%), до інших -у $2,4 \%$. У сільській місцевості етіологічним агентом лептоспірозу в 3 рази частіше були лептоспіри серогрупи icterohaemorrhagiae (47,3\% проти 15,8 \% у жителів міст).

У 2011, 2012, 2014 рр. діагноз лептоспірозу у померлих було встановлено лише з врахуванням сукупності клінічних і патоморфологічних даних (мал. 4). В інші роки показник лабораторно підтвердженого лептоспірозу серед померлих коливався від 50 \% (2008, 2015 рр.) до 100 \% (2006, 2007 рр.). Загалом за весь період спостереження серед летальних випадків, що ввійшли до офріційної статистики, лабораторно підтверджено було лише 59,4 \% (19 пацієнтів).

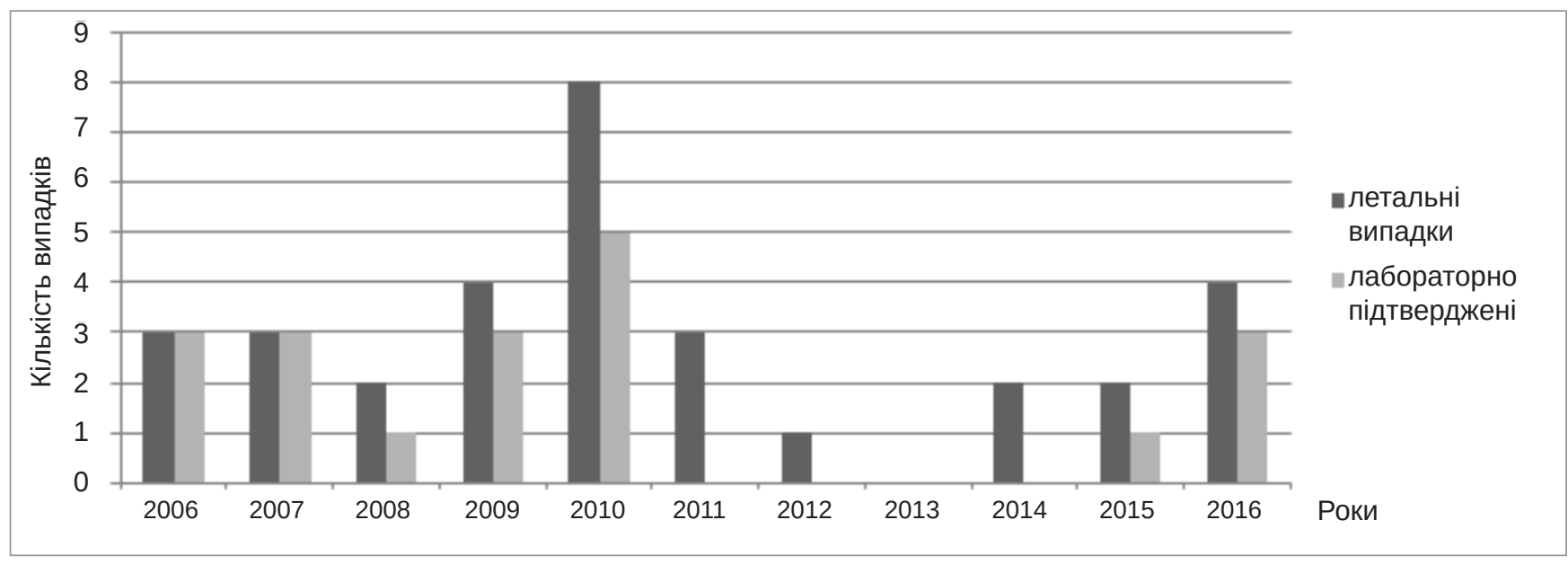

Мал. 4. Динаміка летальних випадків лептоспірозу, зокрема лабораторно підтверджених, у Чернівецькій області (2006-2016 рр.). 
Серед летальних випадків 3 лабораторно підтвердженим діагнозом антитіла до лептоспір icterohaemorrhagiae було виявлено у 12 пацієнтів (63,2 \%) (мал. 5). Рідше виявляли антитіла до лептоспір серогруп grippotyphosa, pomona i tarassovi (21,0, 10,5 і 5,3 \% відповідно). Одночасно антитіла до кількох серогруп було виявлено у 6 померлих (31,6 \% 3 лабораторно підтверджених випадків). У таких випадках при встановленні етіологічного діагнозу враховували найвищі титри антитіл до лептоспір тієї чи іншої серогрупи. Відсутність антитіл спостерігали при 40,6 \% летальних випадків.

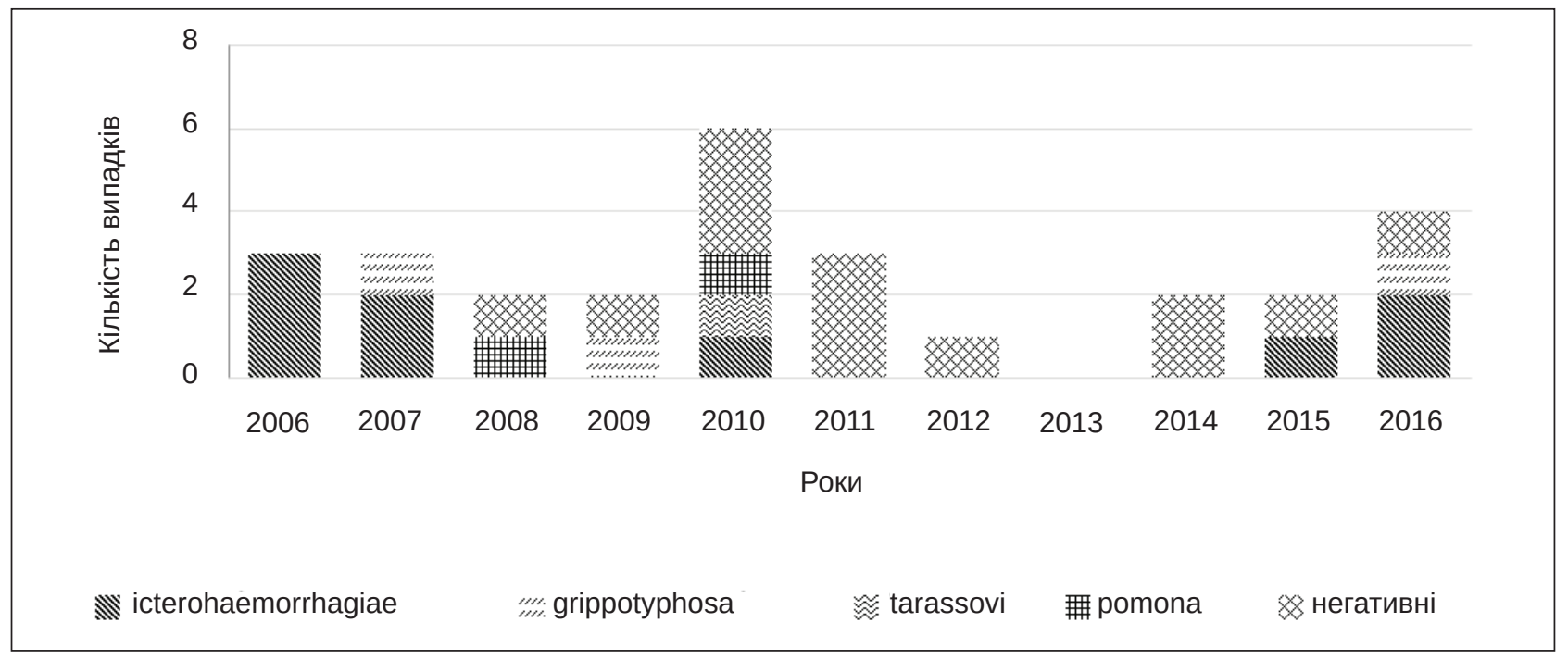

Мал. 5. Етіологічна структура летальних випадків при лептоспірозі в Чернівецькій області (2006-2016рр.).

Виходячи з наведених даних, можна вважати, що ступінь тяжкості та вища летальність протягом періоду спостереження були пов'язані з переважанням L. icterohaemorrhagiae як етіологічного агента.

Було проаналізовано строки звернення за медичною допомогою тих осіб, які померли від лептоспірозу. у перші 2 доби від початку захворювання за медичною допомогою звернулося лише 5 захворілих (15,6 \%), на 3-4-у добу - 8 (25,0 \%), на 5-6-у - 9 (28,1 \%), на 7-10-у добу хвороби - 10 (31,3 \%). Загалом на 5-10-у добу звернулося 59,4 \% пацієнтів, у яких захворювання закінчилося летально, проти 44,1 \% (125 осіб) успішно вилікуваних. Під час усного опитування мешканців сільських населених пунктів регіону, у ході якого було проведено бесіди зі 157 респондентами, лише кожен десятий був обізнаний про цю інфекцію, і жоден 3 опитаних не виявив загальних знань із профрілактики цієї хвороби. Таким чином, недостатню поінформованість населення можна розглядати як одну з причин пізнього звернення за медичною допомогою.

Але не меншою проблемою $є$ несвоєчасна постановка і верифікація діагнозу вже в лікувальному закладі. У 12,5 \% померлих діагноз встановлено лише на 2-6-й дні після звернення за медичною допомогою. Привертає увагу той фракт, що частка правильно постав- лених первинних діагнозів із року в рік знижується. Збіг первинного і кінцевого діагнозів зареєстровано лише в 3,4-23,3 \% випадків лептоспірозу впродовж періоду досліджень, що разом із пізнім зверненням пацієнтів відтерміновує призначення адекватного лікування та впливає на результат захворювання. На жаль, натепер лептоспіроз частково поповнює статистику соматичних та інших інфекційних хвороб, причинами чого, крім клінічного поліморфізму, ймовірно, є відсутність настороги у лікарів первинної ланки та труднощі при ранній лабораторній діагностиці (відсутність специорічних антитіл у хворих при фрулмінантному перебігу і при деяких атипових проявах захворювання, таких як лептоспірозний менінгіт, менінгоенцефраліт та ін.).

У зв'язку з гіподіагностикою в Чернівецькій області та загалом по Україні, як і в більшості інших європейських країн, офріційно зареєстрована захворюваність на лептоспіроз серед населення не відповідає об'єктивному прояву епідемічного процесу. Разом з тим, наказом МО3 України від 28.12.2015 р. № 905 [12] передбачено використання чітких клінічних критеріїв, за якими випадок класифікують як можливий або ймовірний, а саме наявність гарячки або принаймні двох з одинадцяти симптомів: озноб, головний біль, міалгія, гіперемія кон'юнктиви, крововиливи в шкіру і слизові оболонки, висип, 
жовтяниця, міокардит, менінгіт, ниркова недостатність, респіраторні прояви, кровохаркання. Визначено лабораторні критерії для підтвердження випадку: виділення Leptospira interrogans або інших патогенних Leptospira spp. 3 клінічних зразків; виявлення нуклеїнових кислот Leptospira interrogans або інших патогенних Leptospira spp. в клінічних зразках; Leptospira interrogans або інших патогенних Leptospira spp. в клінічних зразках методом імуносрлюоресценції; антитіл до Leptospira interrogans або інших патогенних Leptospira spp. методом реакції мікроаглютинації з використанням діагностичних штамів лептоспір. 3 епідеміологічних критеріїв мають бути враховані один з таких, як передача від тварини до людини, вплив навколишнього середовища, вплив спільного джерела. Врахування зазначених вище критеріїв дасть можливість поліпшити діагностику лептоспірозу практикуючими лікарями та підвищити ефективність лікування.

\section{Висновки}

1. На сьогодні лептоспіроз серед зоонозних інфеекційних хвороб залишається одним із значних викликів громадському здоров'ю Чернівецької області. Впродовж 2006-2016 рр. було зареєстровано 283 випадки цієї інфекції. На тлі тенденції до зниження захворюваності спостерігалася стійка тенденція до зростання летальності. IІї середній показник впродовж 2006-2016 рр. складав 11,3 \% при загальнодержавному 9,6 \% та в окремі роки коливався від 3,6 \% (2008 р.) до 57,1% (2016 р.).

\section{Література}

1. Global morbidity and mortality of leptospirosis: a systematic review / F. Costa, J.E. Hagan, J. Calcagno [et al.] // PLoS Negl. Trop. Dis. - 2015. - № 9: e0003898. https://doi.org/10.1371/journal. pntd.0003898.

2. Annual epidemiological report 2014 - food- and waterborne diseases and zoonoses. - European Centre for Disease Prevention and Control. 2014. [E-resource] http://ecdc.europa.eu/en/publications/ Publications/food-waterborne-diseases-annual-epidemiologicalreport-2014.pdf

3. Richard S. Zoonotic occupational diseases in forestry workers - Lyme borreliosis, tularemia and leptospirosis in Europe / S. Richard, A. Oppliger // Ann. Agric. Environ. Med. - 2015. - Vol. 22, N 1. - P. 43-50.

4. Picardeau M. Diagnosis and epidemiology of leptospirosis / M. Picardeau // Med. Mal. Infect. - 2013. - Vol. 43, N 1. - P. 1-9.

5. Globalization of leptospirosis through travel and migration / Bandara M., Ananda M., Wickramage K. [et al.] // Global Health. 2014. - N 10. - P. 61. [E-resource] https://www.ncbi.nlm.nih.gov/ pubmed/25112368

6. Haake D.A. Leptospirosis in humans / D.A. Haake, P.N. Levett // Curr. Top. Microbiol. Immunol. - 2015. - Vol. 387. - P. 65-97.

7. Leptospirosis in Mexico: Epidemiology and potential distribution of human cases / S. Sánchez-Monte, D.V. Espinosa-Martínez,
2. Серед фракторів ризику стосовно тяжкого ступеня лептоспірозу та вищої летальності слід зазначити етіологічну роль L. icterohaemorrhagiae, вік 60 років і старше, пізнє звернення, пізню постановку діагнозу. Серед пацієнтів із лабораторно підтвердженим діагнозом антитіла до лептоспір icterohaemorrhagiae було виявлено у $61,8 \%$ пацієнтів із тяжким перебігом захворювання та у 63,2 \% померлих від лептоспірозу, у той час, як серед усіх захворілих цей показник становив лише 33,7 \%. Серед пацієнтів, які померли, особи віком 60 років і старше становили $62,5 \%$. За медичною допомогою на 5-10-у добу звернулося 59,4 \% осіб проти 44,1 \%, у яких захворювання закінчилося одужанням. У 12,5 \% померлих діагноз було встановлено на 2-6-й дні після звернення. Збіг первинного і кінцевого діагнозів зареєстровано лише в 3,4-23,3 \% випадків лептоспірозу. Серед летальних випадків, що ввійшли до офріційної статистики, лабораторно підтверджено було лише 59,4 \%.

3. Пізнє звернення за медичною допомогою обумовлено низькою обізнаністю населення про лептоспіроз. Серед опитаних сільських жителів лише кожен десятий знав про цю інфекцію.

4. Як серед захворілих на лептоспіроз, так і серед померлих переважали сільські жителі (відповідно 74,6 та 65,6 \%), що пов'язано з вищим ризиком їх інфрікування в результаті сільськогосподарських робіт.
C.A. Ríos-Muñoz [et al.] // PLoS One. - 2015. - Vol. 10, N 7: e0133720. [E-resource] https://doi.org/10.1371/journal.pone.0133720

8. Leptospirosis in Tropical Regions of Southeast Mexico: A Clinical Case Series Review / A.E. Svarch, C.A. Arce-Salinas, J.L. Amaya, M.N. Garcia // Current Tropical Medical Report. - 2017. - Vol. 4, N 2. P. 52-56. [E-resource] https://doi.org/10.1007/s40475-017-0104-8

9. Епідеміологічні особливості лептоспірозу в західному регіоні України / Н.А. Васильєва, Ю.А. Поліщук, О.Л. Івахів [та ін.] // Інфекційні хвороби. - 2008. - № 2. - С. 15-19.

10. Кравчук Ю.А. Епізоотолого-епідеміологічні особливості лептоспірозу в Тернопільській області / Ю.А. Кравчук, Н.А. Васильєва // Анали Мечниковського інституту. - 2015. - № 2. - С. 165-171.

11. Goris M.G.A. Leptospirosis serodiagnosis by the microscopic agglutination test / M.G.A. Goris, R.A. Hartskeerl // Curr. Protoc. Microbiol. - 2014. - Vol. 32, N 1. - P. 12E.5.1-12E.5.18. [E-resource] https://currentprotocols.onlinelibrary.wiley.com/doi/ pdf/10.1002/9780471729259.mc12e05s32

12. Наказ МОЗ України від 28.12.2015р № 905 «Про затвердження критеріїв, за якими визначаються випадки інсрекційних та паразитарних захворювань, які підлягають реєстрації». [E-resource] http://search.ligazakon.ua/l_doc2.nsf/link1/RE28509.html 


\section{References}

1. Costa, F., Hagan, J.E., Calcagno, J., Kane, M., Torgerson, P., Martinez-Silveira, M.S. (2015). Global morbidity and mortality of leptospirosis: a systematic review. PLoS Negl. Trop. Dis., 9: e0003898. [E-resource] https://doi.org/10.1371/journal.pntd.0003898.

2. European Centre for Disease Prevention and Control. (2014). Annual epidemiological report 2014 - food- and waterborne diseases and zoonoses. [E-resource] http://ecdc.europa.eu/en/publications/ Publications/food-waterborne-diseases-annual-epidemiologicalreport-2014.pdf

3. Richard, S., Oppliger, A. (2015). Zoonotic occupational diseases in forestry workers - Lyme borreliosis, tularemia and leptospirosis in Europe. Ann. Agric. Environ. Med., 22, 1: 43-50.

4. Picardeau M. (2013). Diagnosis and epidemiology of leptospirosis. Med. Mal. Infect., 43, 1: 1-9.

5. Bandara, M., Ananda, M., Wickramage, K., Berger, E., Agampodi, S. (2014). Globalization of leptospirosis through travel and migration. Global Health., 10: 61. [E-resource] https://www.ncbi.nIm. nih.gov/pubmed/25112368

6. Haake, D.A., Levett, P.N. (2015). Leptospirosis in humans. Curr. Top. Microbiol. Immunol., 387: 65-97.

7. Sánchez-Monte, S., Espinosa-Martínez, D.V., Ríos-Muñoz, C.A., Berzunza-Cruz, M., Becker, I. (2015). Leptospirosis in Mexico: Epidemiology and potential distribution of human cases. PLoS One, 10, 7: e0133720. [E-resource] https://doi.org/10.1371/journal. pone. 0133720

\section{CHARACTERISTICS OF LETHALITY IN LEPTOSPIROSIS IN THE CHERNIVTSI REGION}

V.I. Zadorozhna, N.V. Hopko

L.V. Gromashevsky Institute of Epidemiology and Infectious Diseases NAMS of Ukraine, Chernivtsi Regional Laboratory Center of the Ministry of Health of Ukraine

SUMMARY. Leptospirosis is one of the greatest challenges to the public health of the Chernivtsi region among zoonotic infectious diseases.

The aim is the characteristic of lethality in leptospirosis on the example of Chernivtsi region. and determining the factors that increase its risk.

Materials and methods. The epidemiological, serological and statistical methods of research were used, the data of the State Institution "Chernivtsi Regional Laboratory Center of the Ministry of Health of Ukraine» (2006-2016) on the morbidity and mortality rate in leptospirosis in the region, the results of the epidemiological investigation of all registered cases of leptospirosis (283 cases, in particular 32 lethal), the results of an oral interview of 157 respondents to assess the rural population's awareness of leptospirosis were used. The etiology of the disease was determined by the presence
8. Svarch, A.E., Arce-Salinas, C.A., Amaya, J.L., Garcia, M.N. (2017). Leptospirosis in Tropical Regions of Southeast Mexico: A Clinical Case Series Review. Current Tropical Medical Report (2017) 4: 52. [E-resource] https://doi.org/10.1007/s40475-017-0104-8

9. Vasylieva, N.A., Polishchuk, Yu.A., Ivakhiv, O.L., Burtnyak, T.V., Musiienko, M.T. (2008). Epidemiolohichni osoblyvosti leptospirozu v zakhidnomu rehioni Ukrainy [Epidemiological features of leptospirosis in the western region of Ukraine]. Infektsiyni khvoroby, 2: 15-19. [in Ukrainian].

10. Kravchuk, Yu.A., Vasylieva, N.A. (2015). Epizootolohoepidemiolohichni osoblyvosti leptospirozu v Ternopilskii oblasti [Epizootological and epidemiological features of leptospirosis in the Ternopil region]. Analy Mechnykovskoho instytutu, 2: 165-171. [in Ukrainian].

11. Goris, M.G.A., Hartskeerl, R.A. (2014). Leptospirosis serodiagnosis by the microscopic agglutination test. Curr. Protoc. Microbiol., 32, 1: 12E.5.1-12E.5.18. [E-resource] https://currentprotocols.onlinelibrary. wiley.com/doi/pdf/10.1002/9780471729259.mc12e05s32

12. Nakaz MOZ Ukrayiny vid 28.12.2015 r. №905 «Pro zatverdzhennya kryteriyiv, za yakymy vyznachayutsya vypadky infektsiynykh ta parazytarnykh zakhvoryuvan, yaki pidlyahayut reyestratsiyis [On approval of the criteria for determining the cases of infectious and parasitic diseases that are subject to registration"] [E-resource] http:// search.ligazakon.ua/l_doc2.nsf/link1/RE28509.html [in Ukrainian]

of specific antibodies in the reaction of microagglutination using a non-commercial diagnostic set of strains of leptospiros.

Results and conclusions. Against the background of the tendency to decrease the incidence during the observation period in the Chernivtsi , region steady tendency towards a mortality rate has been observed. Its average rate was $11.3 \%$ at the national level - $9.6 \%$, and in some years ranged from $3.6 \%$ (2008) to $57.1 \%$ (2016). Among fatal cases, only $59.4 \%$ of the cases were laboratory confirmed. Among the risk factors for severe clinical course and higher mortality, it should be noted the etiological role of $L$. icterohaemorrhagiae, the age of patients 60 years and older, late medical treatment, late diagnosis after treatment. Among patients with a laboratory-confirmed diagnosis the antibodies to L. icterohaemorrhagiae were detected in $61.8 \%$ of the patients with severe disease and in $63.2 \%$ of the dead. Among all the patients, this figure was only $33.7 \%$. Among the patients who died, $62.5 \%$ were persons aged 60 years and older. For medical assistance, on the 5th-10th day, $59.4 \%$ of the people against $44.1 \%$ approached the disease, in which the disease ended in recovery. Late appeal for medical care is due to low awareness of the population. Only one in ten among 


\section{ОРИГІНАЛЬНІ ДОСЛІДЖЕННЯ}

respondents from rural areas noted awareness about this infection. The coincidence of primary and final diagnoses was registered only in 3.4-23.3\% of cases. Among the patients with leptospirosis and among the deceased, rural residents (74.6\% and $65.6 \%$ respectively) prevailed.

Key words: leptospirosis, lethality in leptospirosis L. icterohaemorrhagiae.

\section{Відомості про авторів:}

Задорожна В.І. - директор ДУ «Інститут епідеміології та інсрекційних хвороб ім. Л.В. Громашевського НАМН України», д. мед. н., профресор, член-кореспондент НАМН України; e-mail: viz2010@ukr.net

Гопко Н.В. - В. о. директора ДУ «Чернівецький обласний лабораторний центр МО3 України»; e-mail: gopkonv@ gmail.com

\section{Information about the authors:}

Zadorozhna V. - Head of the State Institution «L.V. Hromashevskyi Institute of Epidemiology and Infectious Diseases of the NAMS of Ukraine», Professor, Doctor of Medicine; e-mail: viz2010@ukr.net

Hopko N. - Acting Director of the State Institution «Chernivtsi Regional Laboratory Center of the Ministry of Health of Ukraine»; e-mail: gopkonv@gmail.com

Конфрлікту інтересів немає.

Authors have no conflict of interest to declare.

Отримано 26.03.2018 p. 